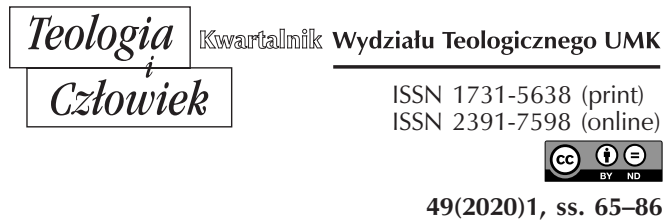

SŁAWOMIR ZATWARDNICKI

\title{
ISTOTNE KOMPONENTY MŁODOŚCI W ŚWIETLE CHRYSTOLOGIl
}

DOI: http://dx.doi.org/10.12775/TiCz.2020.004

Streszczenie. Autor artykułu zinterpretował młodość Chrystusa opisaną w Ewangelii św. Łukasza, wykorzystując do tego celu doktrynę chrystologiczną jako klucz hermeneutyczny badań. W całym procesie poszukiwano „objawień antropologicznych” dających się wyprowadzić z chrystologii. W efekcie udało się sformułować istotne komponenty „młodości teologicznej”. Młodość jest czasem rozpoznawania własnej tożsamości w Bogu oraz odnalezienia swojego miejsca w realizacji Bożego planu. Quo non est assumptum non est sanatum zinterpretowane dynamicznie oznacza, że Chrystus sprostał wymaganiom czasu dojrzewania, odkupiając okres młodości. Umożliwił młodemu człowiekowi udział w swoim modlitewnym synowskim dialogu z Ojcem oraz w płynącym z modlitwy „wol-

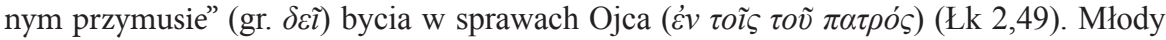
człowiek zostaje wezwany do zaangażowania się w ewangelizację oraz do pełnienia misji prorockiej w Kościele. Na ile jego chrześcijańskie życie odpowiada misterium Kościoła, na tyle wolno mu kwestionować kościelne status quo.

Słowa kluczowe: Słowo Wcielone; relacja antropologia-chrystologia; młodość teologiczna; modlitwa Syna; bycie w sprawach Ojca; quod non est assumptum non est sanatum; ewangelizacja i misja prorocka.

Abstract. Youth in the Light of Christology. The author of the article interpreted Christ's youth described in the Gospel of Luke using Christological doctrine as 
a hermeneutical key of his studies in order to achieve that. 'Anthropological revelations' that are to be derived from Christology were sought for in the whole process. Significant components of 'theological youth' were formulated as a result. Youth is the time of discovering one's own identity in God and finding one's place in fulfilling God's plan. Quo non est assumptum non est sanatum interpreted dynamically means that Christ met the requirements of the time of adolescence redeeming thus the period of youth. He enabled a young person to take part in His prayerful filial dialogue with the Father, as well as in 'free compulsion'(gr. $\delta \varepsilon \tilde{\imath}$ ), which flows from prayer, of being about the affairs of the

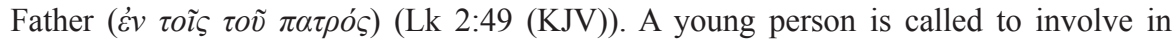
evangelization and carry out a prophetic mission in the Church. They may challenge the ecclesiastical status quo depending on how much their Christian life complies with the mystery of the Church.

Keywords: Incarnated Word; relation between anthropology and Christology; theological youth; Son's prayer; be about the affairs of the Father; quod non est assumptum non est sanatum; evangelization and prophetic mission.

Angielski teolog Simon Oliver, definiując jedno z założeń ruchu Radical Orthodoxy, przywołał nośną sentencję: podczas gdy dyskursy pozateologiczne chcą powiedzieć wszystko o czymś (ang. say everything about something), teologia próbuje mówić coś o wszystkim (ang. say something about everything) ${ }^{1}$. Gdy teolog rezygnuje $\mathrm{z}$ tego zadania, wtedy scientia fidei nie wnosi właściwego jej poznania do badanych zagadnień. Jest niepokojące, że temat młodości - czyli okresu życia zawartego między dzieciństwem a wiekiem dojrzałym - nie zajął do tej pory polskich teologów (por. Bibliografia Nauk Teologicznych FIDES²). Pojawia się ryzyko przyjmowania „na wiarę" interpretacji młodości dokonywanych przez dyscypliny psychologiczne czy pedagogiczne. W niniejszym tekście, którym przerywam to milczenie, zakładam, że „młodość teologiczna” różni się od młodości pojmowanej w ramach psychofizycznego dojrzewania. Stawiam pytanie o istotne komponenty młodości, które ukazują się w świetle Wcielonego Syna.

${ }^{1}$ Por. The Radical Orthodoxy Reader, ed. J. Milbank, S. Oliver, New York 2009, s. 19. Sentencja ta, do której odwołuje się John Milbank, postać kluczowa dla Radical Orthodoxy, pochodzi od Nicholasa Lasha - por. tamże, s. 36.

${ }^{2}$ Por. http://biblio.fides.org.pl (data dostępu: 02.07.2019). 
Ponieważ kwestia ta winna być rozpatrywana w ramach związku antropologii z chrystologią, należało najpierw nakreślić sposób wyciągania wniosków antropologicznych z chrystologii, co czynię w paragrafie pierwszym. W paragrafie drugim wskazuję istotne chrystologiczne i soteriologiczne prawdy, na podstawie których prowadzę następnie poszukiwania antropologiczne. W paragrafie trzecim interpretuję młodość Chrystusa opisaną w Ewangelii św. Łukasza, wykorzystując do tego celu klucz hermeneutyczny chrystologicznej doktryny przywołanej w paragrafie drugim. W swoich refleksjach skupiam się na epizodach: zgubienia się nastoletniego Żyda w świątyni oraz chrztu dorosłego mężczyzny. Dzięki temu w paragrafie czwartym będę mógł sformułować istotne komponenty „młodości teologicznej” i na ich podstawie wytyczyć również wskazania pastoralne ${ }^{3}$.

\section{METAUWAGI WSTĘPNE}

Stwierdzenie, że Syn Boży stał się człowiekiem (por. J 1,14) oznacza, że coś o sobie, jako ludziach, wiemy. Wszelako nie wolno objawienia sprowadzać do jedynie dodatkowej informacji względem naturalnej wiedzy. Jeśli wolno w refleksji o człowieku poruszać się po kole hermeneutycznym, to należy przyznać supremację chrystologii nad antropologią - nie „nasze” człowieczeństwo stanowi miarę dla Inkarnacji, ale odwrotnie. Ta aporia pierwszeństwa chrystologii nad antropologią będzie decydująca dla dalszych rozważań.

Nie jest jednak do końca poprawna konstatacja, że skoro Słowo stało się człowiekiem, to w człowieczeństwie Wcielonego, jak w lustrze, odbija się nasze człowieczeństwo. Wcielony jest „Bogiem prawdziwym”, który stał się verus homo nie przestając być verus Deus, a inkarnacja dokonała się nie tylko propter nos homines, ale i propter nostram salutem. Dlatego może być Wcielony prawdziwym człowiekiem, że jest prawdziwym Bogiem. A celem Jego przyjścia jest pożytek ludzi oraz ich zbawienie. Widzimy nie bezpośrednie objawienie się człowieka w Chrystusie, lecz

3 Artykuł jest zmodyfikowaną wersją wystąpienia wygłoszonego 26 lutego 2019 roku w ramach 51 Tygodnia Eklezjologicznego w Lublinie. 
pośrednie. Patrzący na Chrystusa musi dostrzec równocześnie: doskonałe człowieczeństwo Syna, który stał się człowiekiem; Jego dźwiganie naszej ludzkiej upadłej kondycji; siebie upadłych a mimo wszystko umiłowanych „do końca”; Zbawiciela, który ukazuje zarówno istotę grzechu, jak i drogę, którą należy iść ku wyzwoleniu.

Chrystus, powiedzmy sugestywnie za Peterem Kreeftem, is an $x$-ray mirror: when we look at Him, we see our own depth ${ }^{4}$. Obraz ten należy dopełnić: dostrzegamy nie tylko głębię człowieczeństwa, ale również w sposób pośredni otchłań grzechu. Rentgenowskie lustro odzwierciedla pozytywne aspekty człowieka, we Wcielonym jaśniejące na sposób wyjątkowy (unia hipostatyczna). Ale ukazuje też ciemne plamy choroby człowieka widocznej, na zasadzie negatywu, w drodze Chrystusa idącego „pod górę" ludzkiego upadku. Sprawę komplikuje fakt, że zarówno na Słowo Wcielone, jak i na człowieka, należałoby patrzeć dynamicznie, a nie statycznie. W tym sensie trzeba by mówić nie tyle o rentgenowskim pojedynczym kadrze, ile o całym filmie.

Tak, że „teraz oglądamy przez zwierciadło, w ukryciu zagadki, a wówczas - twarzą w twarz; teraz poznaję cząstkowo, a wówczas poznam w pełni, jak i zostałem poznany" (1 Kor 13,12). Być może lepiej byłoby mówić nie tyle o poznawaniu człowieka w Chrystusie, ile o poznaniu człowieka przez Chrystusa, z czego dopiero wtórnie wynikałoby objawienie antropologiczne (por. 1 Kor 13,12). Problemu człowieka się nie rozwiązuje, raczej jedna tajemnica, ludzka, przegląda się w drugiej, w misterium Chrystusa ${ }^{5}$.

\section{CHRYSTOLOGICZNE DROGOWSKAZY}

\subsection{HUMANIZACJA CZŁOWIEKA NIE BEZ PRZEBÓSTWIENIA}

Jezus Chrystus to, zgodnie z definicją Chalcedonu (451 rok),

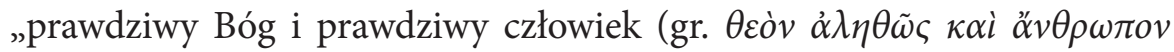

${ }^{4}$ P. Kreeft, The Philosophy of Jesus, South Band, Indiana 2007, s. 74.

${ }^{5}$ Por. Jan Paweł II, Encyklika Redemptor Hominis, Watykan 1979, 8. Por. Sobór Watykański II, Konstytucja duszpasterska o Kościele w świecie współczesnym Gaudium et spes, 22; G. O'Collins, Revelation. Towards a Christian Interpretation of God's Self-revelation in Jesus Christ, Oxford 2016, s. 80; T.G. Weinandy, Jesus the Christ, [b.m.] 2017, s. 170-171. 
$\dot{\alpha} \lambda \eta \theta \tilde{\omega} \varsigma)$, złożony z duszy rozumnej i ciała, współistotny Ojcu co do Bóstwa i współistotny nam co do człowieczeństwa"6. Właśnie i tylko dlatego, że Wcielony nie jest kimś innym od prawdziwego Syna Bożego, można w Nim ujrzeć prawdziwego człowieka ${ }^{7}$.

Oznacza to, że pełnia i doskonałość człowieczeństwa jest konstytuowana przez unię z Bogiem. Ostatecznie nie jest możliwa humanizacja bez przebóstwienia, innymi słowy: dopiero przebóstwienie „czyni człowieka doskonale ludzkim: przebóstwienie jest prawdziwą i najwyższą „humanizacją" człowieka"s.

\subsection{QUO NON EST ASSUMPTUM NON EST SANATUM}

In the Incarnation the Son of God did not assume some generic humanity but our own sinful humanity, ponieważ, przekonuje Thomas Weinandy, only if the Son of God assumed our fallen nature could he heal it and save it. Soteriologiczna wartość Wcielenia opiera się na fakcie, że swoje synostwo przeżywa Syn po ludzku, w warunkach pogrzechowych ${ }^{9}$, idąc jakby „pod prąd” upadłej ludzkości (por. Rz 8,3).

Patrystyczny aksjomat quo non est assumptum non est sanatum ${ }^{10}$ trzeba odczytywać nie tylko statycznie, odnosząc do elementów ludzkiej natury, ale również dynamicznie, uwzględniając czas, w którym Wcielony w ziemskiej historii dokonuje odkupienia. Tutaj należy sytuować problem młodości odkupionej przez Wcielonego, który również ten wiek dorastania w grzesznym świecie przeżył nieskalanie.

Jeśli Słowo stało się ciałem, to stało się również historią. Ontologiczne stwierdzenia Soboru w Chalcedonie należy czytać także egzystencjalnie, mając na uwadze historyczny wymiar Chrystusowego człowieczeństwa będącego nieustannie „w drodze”, a nawet w rozwoju. Ewan-

${ }^{6}$ Sobór Chalcedoński, Definicja wiary, 11.

7 A. Riches, Ecce homo. On the Divine Unity of Christ, Grand Rapids, Michigan 2016, s. xvii.

${ }^{8}$ Międzynarodowa Komisja Teologiczna, Teologia, chrystologia, antropologia, I, E, 4.

${ }^{9}$ Por. T.G. Weinandy, Jesus the Christ, dz. cyt., s. 99. Por. również: G.L. Müller, Dogmatyka katolicka, tłum. W. Szymona, Kraków 2015, s. 399.

${ }_{10}$ Por. Grzegorz z Nazjanzu, Epistola CI (PG 37, 181-184). 
gelijne wydarzenia historyczne są jak gdyby „przekładem” ontologii na historyczne dzieje ${ }^{11}$.

\subsection{ADMIRABILE COMMERCIUM W MODLITWIE CHRYSTUSA}

Chalcedoński oroৎ należy koniecznie dopełnić orzeczeniami III Soboru w Konstantynopolu (680-681). Dioteletyzm „dopowiada”, w jaki sposób dwie natury jednoczą się w jednej Osobie, bez zmieszania, ale zarazem bez pozostawania „obok” siebie, dzięki czemu dokonuje się „przedziwna wymiana” (łac. admirabile commercium). Zgoda obu pragnień - niestworzonego i stworzonego - uwidacznia się zwłaszcza w synowskim dialogu Wcielonego z Ojcem. Modlitwa Jezusa ukazuje ontologię Słowa Wcielonego ${ }^{12}$.

Zdaniem Josepha Ratzingera pomimo tego, że inkarnacja dokonała się propter nostram salutem, struktura ontologiczna Jezusa wymagała, żeby był On w komunii z Bogiem również ze względu na samego siebie (propter se). Dlatego w centrum Chrystusowej ontologii wolno umiejscowić modlitwę, i tutaj też należałoby poszukiwać „cudownej wymiany”. Wynikająca z natury relacji Syna z Ojcem konieczność pozostawania w osobistym z Nim dialogu po Wcieleniu oznacza, że w dialog ten „włącza” Wcielony także ludzką duszę ${ }^{13}$. Tym samym Chrystus otwiera drogę do Ojca również nam.

11 Por. A. Riches, After Chalcedon: the Oneness of Christ and the Dyothelite Mediation of his Theandric Unity, „Modern Theology” (2008) nr 2, s. 204; T. Rowland, The Humanism of the Incarnation. Catholic, Barthian, and Dutch Reformed, „Nova et Vetera” (2015) nr 1, s. 135.

12 Por. J. Ratzinger, Bóg Jezusa Chrystusa. Medytacje o Bogu Trójjedynym, tłum. J. Zychowicz, Kraków 1995, s. 82.

${ }^{13}$ Por. J. Ratzinger (Benedykt XVI), Jezus z Nazaretu, cz. 1: Od chrztu w Jordanie do Przemienienia, tłum. W. Szymona, Kraków 2007, s. 22; D.G. Bonagura, Joseph Ratzinger/Benedict XVI's Christology of Jesus' prayer and two contemporary theological questions, „Nova et vetera”, (2014) nr 1, s. 298-299; A. Riches, After Chalcedon, s. 200. 


\section{MISTERIUM MŁODOŚCl CHRYSTUSA}

\subsection{NASTOLATEK W SPRAWACH OJCA}

Zasłona milczenia spowijająca okres młodości Chrystusa rozdziera się jeden tylko raz, „gdy skończył dwanaście lat” (Łk 2,42). Udział w uroczystościach Paschy staje się tłem do odsłonięcia tajemnicy Wcielonego Jego posłannictwa i tożsamości ${ }^{14}$, a zarazem jej uświadomienia sobie przez Jezusa na danym etapie rozwoju ludzkiego. Nie jest przypadkiem, że właśnie w tym czasie, kiedy wspominano dawne zbawcze działanie Jahwe, Jezus odkrywa swoją misję - ma On „być w tym, co należy do mojego Ojca” (w. 49). Ukazuje się tutaj zarówno przekonanie młodego Jeszuy, że nie Józef, lecz sam Bóg jest Jego Ojcem, jak i Jego powołanie do bycia w sprawach Ojca. Już teraz łączą się nierozerwalnie Osoba z dziełem Chrystusa (zatem: chrystologia i soteriologia). Posłanie nie jest dodatkiem do Osoby, jakiegoś rodzaju pobożnym „hobby”, ale misją wyzwolenia z duchowego Egiptu, co jawi się najważniejszą „sprawą" Ojca, i konsekwentnie także Syna posłanego dla „tej godziny”. „Gdy uczcili te dni, wracali, a Jezus, chłopiec, został w Jeruzalem” (w. 43). Dla Niego nie tyle jest to uroczystość wspominania, ile wejście $\mathrm{w}$ istotę uroczystości, w której już pozostanie i w którą będzie wnikał całą swoją ludzką duszą.

Treści teologicznej kryjącej się w określeniu wieku Jezusa nie wolno zredukować do tezy, że ewangeliście chodziło o podkreślenie pobożności Maryi i Józefa włączających Jezusa w religijne praktyki rok przed bar micwą. Chłopiec - bo tak Go nazywa Łukasz $^{15}$ - w wieku dwunastu lat, jak uznawano, ani jeszcze nie pozostawił dzieciństwa za sobą, ani jeszcze nie osiągnął pierwszych nawet stopni dojrzałości ${ }^{16}$. Dwunastoletni pozostaje wciąż jeszcze dzieckiem, bo dopiero na tym tle ukazuje się specyfika Jego tożsamości. Nie sięgnie się istoty Jego tożsamości, jeśli nie przyjmie się, że ewangelista chce ukazać kontrast między ,już” i „jeszcze nie”. Już dwunastoletnie Dziecko - zdaje się przekazywać Łukasz - jest przekonane o swojej wyjątkowej

${ }_{14}$ Por. F. Mickiewicz, Ewangelia według świętego Łukasza. Rozdziały 1-11. Wstęp, przekład z oryginału i komentarz, Częstochowa 2011, s. 197.

15 Por. F. Mickiewicz, dz. cyt., s. 199.

16 Por. H.J. de Jonge, Sonship, wisdom, infancy: Luke 2:41-51a, „New Testament Studies" (1978) nr 3, s. 319-321. 
relacji z Bogiem, i właśnie ten synowski stosunek do Ojca powoduje Jego późniejsze ludzkie dojrzewanie do tego, kim już jest. Co prawda „wszyscy słyszący Go byli zdumieni Jego rozumem i wypowiedziami” (w. 47), ale przecież nie znaleźli genezy Jego tożsamości, nie zauważyli, że przebywa chłopiec u Ojca, i to źródło zasila Jego ludzki rozwój powodując: „postępy w mądrości, w dojrzałości w łasce u Boga i u ludzi” (w. 52).

Maryja i Józef „myśleli, że On jest gdzieś w grupie pielgrzymów” (w. 44), ale On nie jest pielgrzymem, On już dotarł do celu pielgrzymki, nawet jeśli w ludzkiej świadomości będzie Mu jeszcze trzeba wędrować. „Zagubił” się również nauczycielom świątynnym, którym się przysłuchiwał i którym zadawał pytania (w. 44-46). Młody Jezus odkrywa swoją specyfikę na tym właśnie religijnym tle, względem którego pozostaje w relacji zarówno ciągłości, jak i braku ciągłości oraz postępu ${ }^{17}$.

Istotna dla zrozumienia relacji między chrystologią ontologiczną a egzystencjalną jest replika, jakiej Jezus udzielił Rodzicom: „Czy nie wiecie, że ja powinienem być w tym, co należy do mojego Ojca? (gr. oủ

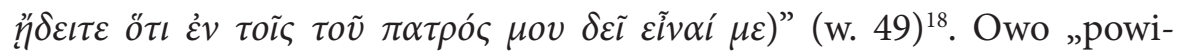
nienem" wskazuje na wolę, na decyzję, którą należało podjąć, żeby być w sprawach Ojca. To, co ontologicznie już jest dane, na planie ludzkim musi być wciąż przeżywane $\mathrm{w}$ dialogu $\mathrm{z}$ Ojcem oraz w posłudze jako wyrazie posłuszeństwa woli Bożej (tożsamość Syna i Posłanego) ${ }^{19}$. Syn jest Synem, bo jest u Ojca, bo Jemu się poddaje w swojej ludzkiej woli.

Można zatem mówić o pewnego rodzaju „potrzebie”20 czy nawet „przymusie” odczuwanym przez Chrystusa. Wynika On z samego faktu bycia Synem - Wcielony chce pełnić wolę Ojca, a nawet powinien $(\delta \varepsilon \tilde{\imath})$ ją realizować. To pragnienie a zarazem konieczność (nie ma między nimi sprzeczności) odczuwane jest także w woli ludzkiej, którą Logos przyjął (greckie słowo $\delta \varepsilon \tilde{\imath}$ zawiera w sobie element konieczności i przymusu).

17 Por. Papieska Komisja Biblijna, Naród żydowski i jego Święte Pisma w Biblii chrześcijańskiej, tłum. R. Rubinkiewicz, Kielce 2002, II, C, 1-3; IV, A (przejmuję wyrażenia, których użyto do opisu relacji między Nowym a Starym Testamentem).

${ }_{18}$ Ściśle rzecz biorąc końcowy fragment należałoby tłumaczyć: „[...] być w... mojego Ojca" - por. F. Mickiewicz, dz. cyt., s. 201.

19 Por. H.H. Langkammer, Komentarz do Ewangelii wg św. Łukasza i Ewangelii wg św. Jana, Poznań 2014, s. 50.

20 Por. F. Mickiewicz, dz. cyt., s. 204. 
„Oni jednak nie zrozumieli słów, które im powiedział” (w. 50). Najwyraźniej nikt z nich nie zwracał się do Boga słowami „Ojciec mój” - tak bliska relacja nie jest nikomu poza Nim dostępna, dlatego wydaje się niezrozumiała; konsekwentnie wyjątkowe, zatem nie do pojęcia, musi być również zaangażowanie się w sprawy Ojca ${ }^{21}$. Nawet dla Maryi „na tamtą chwilę słowa Jezusa są zbyt wielkie. Także wiara Maryi jest wiarą "W drodze»"22. Młody staje się nauczycielem dla Rodziców, podobnie jak wcześniej okazał się nauczycielem dla nauczycieli w Jerozolimie.

$\mathrm{Na}$ razie wróci do Nazaretu i będzie im poddany (w. 51), ale nie jest ten powrót powrotem do przeszłości. Sprawa Boża dominuje nad wszystkim, i dalszy rozwój można interpretować jako dojrzewanie do momentu, w którym Bóg będzie mógł złożyć swoje sprawy w Jego ręce. Trzeba podkreślić zarówno wzrastającą samoświadomość Chrystusa, jak i utrzymującą się pewność tego, kim jest. Mimo tej dla nas niemożliwej do pogodzenia dwubiegunowości, trzeba jednak wyprowadzić teologiczne (a wtórnie antropologiczne) wnioski ze spisanych pod natchnieniem Ducha Św. relacji: w pierwszej słyszymy, że Jezus nazywa Boga Ojcem, a dopiero w drugiej dochodzi nas głos Ojca nazywającego Jezusa Synem.

\subsection{OJCIEC PRZEKAZUJĄCY SPRAWĘ SYNOWl}

Wydarzenie chrztu w Jordanie, odczytane w perspektywie dioteleckiej chrystologii III Soboru w Konstantynopolu, umożliwia lepsze zrozumienie zbawiennej roli „misteriów” ziemskiego życia Wcielonego ${ }^{23}$.

„Jezus jest kimś, nie bójmy się słowa, namiętnie zaangażowanym w sprawy Boga”. - przekonuje Marian Grabowski - „Z opowieści, które docierają do Niego o tym, co dzieje się nad Jordanem, zorientował się, że rozgrywa się tam «sprawa Ojca»"24. W odróżnieniu od innych ludzi,

${ }^{21}$ Por. H.J. de Jonge, dz cyt., s. 334.

${ }^{22}$ Por. J. Ratzinger (Benedykt XVI), Jezus z Nazaretu. Dzieciństwo, tłum. W. Szymona, Kraków 2012, s. 166.

${ }^{23}$ Por. Międzynarodowa Komisja Teologiczna, Wybrane zagadnienia $z$ chrystologii, II, 7.

${ }^{24}$ M. Grabowski, Pomazaniec. Przyczynek do chrystologii filozoficznej, Poznań 2010, s. 118. 
dla których chrzest staje się punktem zwrotnym określającym na nowo ich życie, dla Jezusa teraz rozpoczyna się decydujący czas zbawienia, dla którego został posłany. Być może stanowi też kluczowe egzystencjalne przeżycie tożsamości. Inauguracja działalności publicznej rozpoczyna się od zajęcia miejsca grzeszników - a zatem od antycypacji Krzyża ${ }^{25}$.

Nie mamy wglądu w ludzką duszę Jezusa, dlatego nie wiemy, czy rzeczywiście po raz pierwszy usłyszał od Ojca: „Ty jesteś moim Synem umiłowanym" (w. 22). Wiemy na pewno, że teraz wyraźnie zostaje oznajmiony związek pomiędzy byciem Synem a Tym, w którym Ojciec złożył swoje postanowienia (por. w. 22). O tyle jest Synem, o ile jest Posłanym i realizującym owo posłanie. Być może kenoza Logosu sięga aż tak daleko, że dopiero, gdy antycypuje krzyż, może usłyszeć, że jest Synem Ojca - ze względu na związek bycia Synem z byciem Posłanym? Ścisłość tego związku wolno określić formułą chalcedońską: jaki jest związek między naturami Boską i ludzką jednoczącymi się w jednej Osobie „bez zmieszania” (gr. $\dot{\alpha} \sigma v \gamma \chi v ́ \tau \omega \varsigma)$ i „bez rozdzielania” (gr. $\alpha \delta$ „ $\alpha \iota \rho \varepsilon ́ \tau \omega \varsigma)$, taka też musi być jedność we Wcielonym między Synem a Posłanym. Nie dziwi, że Chrystus zostaje nazwany Synem umiłowanym w momencie, gdy rozpoczyna się publiczna służba zbawienia ${ }^{26}$.

„Gdy cały lud otrzymał chrzest i kiedy również Jezus przyjął chrzest i modlił się, otwarło się niebo [...]” (w. 21). Nie wcześniej, niż gdy zarówno lud, jak i Jezus, przyjęli chrzest. Nie wystarczyłby sam „chrzest solidarności”, potrzeba było złączenia go z modlitwą. Niebo otwiera się, gdy Syn podejmuje misję, dla której przyszedł; kiedy wola Syna łączy się z wolą Ojca. Albo jeszcze inaczej: gdy sprawa Ojca zostaje przekazana w „ręce” Syna, tzn. kiedy znajduje realizację dzięki i przez Jego ludzką wolę.

Dla interesującego nas zagadnienia „rozświetlenia” młodości blaskiem Chrystusa można powiedzieć, że okres dojrzewania kończy się, gdy Chrystus przyjmuje chrzest. W odwołaniu do ówczesnych zwyczajów palestyńskich pisał apostoł o pełnoletniości związanej z prawem spadkowym: „Jak długo dziedzic jest niepełnoletni, niczym się nie różni od

${ }^{25}$ Por. J. Ratzinger (Benedykt XVI), Jezus z Nazaretu, cz. 1, dz. cyt., s. 27-30; F. Mickiewicz, dz. cyt., s. 233.

${ }^{26}$ Por. A. Nichols, Epiphany. A Theological Introduction to Catholicism, [b.m.] 2016, s. 146. 
niewolnika, choć jest panem wszystkiego, lecz podlega różnym opiekunom i rządcom aż do określonego przez ojca czasu" (Ga 4,1-2). Jeśli ojciec wyznaczał moment pełnoletniości potomka w testamencie, a do tego czasu nieletni nie mógł rozporządzać przysługującym mu majątkiem ${ }^{27}$, to $\mathrm{z}$ kolei w Ojcowskim głosie z nieba nazywającym Jezusa „Synem umiłowanym”, w którym „złożyłem swoje postanowienia” (Łk 3,22), trzeba dosłyszeć cezurę odgraniczającą młodość od dojrzałości. Przy czym nie oznacza to, że Wcielony dopiero teraz osiągnął dojrzałość (przestał być nieletni), raczej to sytuacja „dojrzała” („nastąpiło dopełnienie się czasu” - Ga 4,4) do momentu wzięcia spraw Ojca w swoje ręce. Mowa jest nie tyle o dojrzałości Wcielonego, ile o „dojrzałości teologicznej” - dla naszego zbawienia.

\section{MŁODOŚĆ W ŚWIETLE CHRYSTOLOGII}

\section{1. „TEOLOGICZNA MŁODOŚĆ"}

Nie wiemy ani w jakim wieku Chrystus wkroczył w okres młodzieńczy, ani kiedy osiągnął dojrzałość. Dwunastoletni, który jest w fazie rozwoju i z ludzkiej perspektywy nie osiągnął jeszcze stadium dojrzałości ${ }^{28}$, wyłania się jako już „gotowy” w relacji z Bogiem - zna Go jako Ojca i chce (musi) być w Jego sprawach, co nie przekreśla konieczności wzrastania w samorozumieniu, ponieważ „świadomość własnej tożsamości, to coś innego niż sama tożsamość" ${ }^{29}$. Z kolei trzydziestoletni przejmuje sprawy Ojca w swoje ręce jako już dorosły mężczyzna. Jakby ewangelista dawał do zrozumienia, że konieczne jest rozróżnienie „wieku naturalnego” związanego z rozwojem psycho-fizycznym oraz „wieku teologicznego"

${ }^{27}$ M. Ernst, Dojrzały/Pełnoletni, tłum. Ł. Siemieniec, w: Nowy leksykon biblijny, red. F. Kogler, R. Egger-Wenzel, M. Ernst, red. nacz. nauk. wyd. pol. H. Witczyk, Kielce 2011, s. 151; J.A. Fitzmyer, List do Galatów, w: Katolicki komentarz biblijny, dz. cyt., s. 1382; Pismo Święte Starego i Nowego Testamentu. Najnowszy przekład z języków oryginalnych z komentarzem. Opracował Zespół Biblistów Polskich z inicjatywy Towarzystwa Świętego Pawła, Częstochowa 2009, s. 2539; C.S. Keener, Komentarz historyczno-kulturowy do Nowego Testamentu, Warszawa 2000, s. 407.

${ }^{28}$ Por. H.J. de Jonge, dz. cyt., s. 321.

29 M. Grabowski, dz. cyt., s. 112. 
wynikającego z więzi z Bogiem. Są one związane ze sobą, ponieważ Logos po Wcieleniu przeżywa swoje synostwo na ludzkim poziomie proporcjonalnie do naturalnego rozwoju. A jednak nie wolno utożsamiać jednego z drugim, skoro $\mathrm{w}$ relacji Łukasza dają o sobie znać niesprowadzalne do syntezy dwa bieguny: od początku utrzymujące się przekonanie co do własnej tożsamości a zarazem „postępy w mądrości, w dojrzałości” (Łk 2,52). Supremację sprawuje tutaj biegun „już”: właśnie dlatego, że jest Synem, który do Boga zwraca się „Ojcze”, możliwe staje się wzrastanie.

Z tej perspektywy postrzegany wiek młodzieńczy - „teologiczna młodość" - będzie "nadążaniem” w dokonującym się w czasie rozwoju ludzkim za tożsamością otrzymaną od Ojca. Ponieważ od strony Boga i dzięki sakramentom już jest kimś, może w czasie stawać się tym kimś, a następnie żyć w zgodzie $\mathrm{z}$ tym, kim się staje. Idealnie postępy w mądrości i dojrzałości idą w parze za tożsamością otrzymaną od Boga i odkrywaną przez człowieka. Człowieczeństwo tego, który pozostaje bez relacji z Bogiem, lub który zatrzymał się na poziomie „Bozi”, ulega regresji. Człowiek, który zbyt późno zaczyna czynić postępy w życiu duchowym, pewnych spraw nie jest już w stanie nadgonić. Kolejnych etapów dojrzewania nie da się ominąć, i jedynie do pewnego stopnia dzięki łasce Bożej da się wzrastanie przyspieszyć. Nawet tak wielka łaska jak ta, którą został obdarzony św. Paweł, nie zmieni tego, że ze względu na późne poznanie Chrystusa będzie on, według własnego określenia, „niedojrzałym płodem” (1Kor 15,8). Nie dziwi, że w Kościele większą czcią będzie zawsze otaczana Najświętsza Maryja Panna, w której odzwierciedla się w sposób doskonały kompatybilność „wieku teologicznego” i „wieku naturalnego”.

Rozziew między „wiekiem teologicznym” a „wiekiem naturalnym” świadczy o grzechu, który potem, w dorosłości, przyniesie zgubne skutki: „a grzech, gdy dojrzeje, śmierć płodzi” (Jk 1,15). Stąd na dramat Golgoty trzeba spojrzeć również jak na konsekwencję grzechów młodości; skazujący Chrystusa na Ukrzyżowanie nie poznali Ojca wcześniej, dlatego teraz wydają wyrok na Syna. Z tego właśnie powodu Słowo stało się - również młodym - ciałem, żeby wybawić od zgubnego stanu oddalania się wieku naturalnego i teologicznego.

Dokonujący się rozwój młodego człowieka „w łasce u Boga” (Łk 2,52) można postrzegać jako przyjmowanie $\mathrm{w}$ czasie powziętego odwiecznie zamysłu Ojca (por. Ef 1,3-14), wchodzenie egzystencją w rzeczywi- 
stość otrzymanej łaski sakramentalnej - postępowanie „W dojrzałości” (Łk 2,52). Proces ten dokonuje się na skrzyżowaniu wymiarów wertykalnego i horyzontalnego: chodzi o relację tak z Bogiem, jak i z ludźmi („u Boga i u ludzi” - Łk 2,52). Wraz z przyjęciem Chrystusowej zbawczej służby młody człowiek kieruje się ku Bogu jako Ojcu, ale Synem umiłowanym staje się dopiero, gdy zaczyna służyć i gdy znajdą się ci, którym może posługiwać. Dopiero w takim przypadku można mówić o dojrzałości teologicznej. Dlatego od Kościoła należałoby wymagać wskazywania oraz zapewnienia przestrzeni służby dla młodych.

Należy z całą mocą podkreślić, że dla młodości rozumianej jako „Wzrastanie” czy też „wstępowanie” - by zapożyczyć wyrażeń Jana Pawła II z jego listu do młodych - właśnie obcowanie z Bogiem jako Ojcem jest pierwszorzędnym motorem postępów w mądrości i dojrzałości (por. Łk 2,52) ${ }^{30}$. Jest „znamienne, że nie zachowała się żadna tradycja «świeckiego» życia Jezusa. Wszystkie tradycje mają charakter ściśle religijny"31. Nie oznacza to, że młodzi ludzie mają zrezygnować ze świeckiego życia, lecz że wszystko winno zostać włączone w sprawy Ojca. Akcja zbawcza została wszczęta ze względu na utratę związku z sacrum.

Symptomatyczne, jak bardzo powyższe stwierdzenia idą na przekór współczesnej mentalności. Sprawy Boże wydają się dzisiejszemu młodemu - a czy nie również nam? - pewnego rodzaju „pobożnym hobby”. Tymczasem młodość rozpatrywana z perspektywy Chrystusa ukazuje, że dopiero będąc i żyjąc w Bogu - można być sobą; innymi słowy: dopiero droga ku Bogu prowadzi ku samemu sobie. Czy Jezus z Ewangelii nie dlatego jawi się zintegrowanym, wolnym i pełnym mądrości („skąd Mu to?” - por. Mk 6,2), że cały Jego ludzki rozwój koncentrował się wokół centrum, jakim było odniesienie do Ojca i Jego spraw? U Dwunastoletniego nie znajdzie się cienia patologii, za to dają o sobie znać niespotykana u nastolatków

${ }^{30}$ Por. Jan Paweł II, List do młodych całego świata Parati semper, 14; Rada ds. Duszpasterstwa Młodzieży, Młodość z Chrystusem. Biskupi polscy do młodzieży, Tarnów 2008, s. 14; P. Sokołowski, Chrystocentryzm młodości w orędziach Jana Pawła II, Benedykta XVI i Franciszka na Światowe Dni Młodzieży, „Ateneum kapłańskie” (2016) t. 167 , z. 1 , s. 45 .

${ }^{31}$ Por. Cz.S. Bartnik, Dogmatyka katolicka, t. I: Traktaty I-VI, Lublin 2012, dz. cyt., s. 588 . 
bystrość umysłu, asertywność i zdolność do tworzenia zdrowych relacji ${ }^{32}$. Potwierdza się proporcjonalność humanizacji do przebóstwienia.

\subsection{MŁODOŚĆ ODKUPIONA}

Quo non est assumptum non est sanatum należy interpretować również dynamicznie: Chrystus sprostał wymaganiom każdego wieku ${ }^{33}$. Właśnie dlatego, że Wcielony przeżył etap młodości w sposób doskonały, stawiając Ojca ponad wszystko ${ }^{34}$, młodość mogła zostać odkupiona. Nie chodzi o „automatyczną" zależność: Bóg staje się młodym, aby młody mógł stać się Bogiem. Raczej dlatego, że Logos dźwiga naszą naturę również w czasie jej młodości, i przez tę młodzieńczą fazę przechodzi nienaruszony w swojej relacji z Ojcem, dojrzewając do wypełnienia zleconej Mu misji, jest możliwe utożsamienie się Baranka Bożego z grzesznikami we chrzcie $\mathrm{w}$ Jordanie, a w przyszłości przyjęcie zbawiennego Krzyża: „Mam chrzest przyjąć i jakież ogarnia mnie pragnienie, żeby już się spełnił" (Łk 12,50).

W światłach Objawienia młodość jawi się odkupiona przez Chrystusa: „Napisałem wam, młodzieży, że jesteście mocni i że słowo Boga w was się znajduje, i że dostąpiliście zwycięstwa nad owym zepsutym" (1 J 2,14). Jak Chrystus usłyszał, że jest Synem umiłowanym, gdy rozpoczął swoją publiczną służbę, tak młody staje się synem adoptowanym, gdy przyjmuje tę odkupieńczą służbę Wcielonego. Pismo powiada, że „będą patrzeć na Tego, którego przekłuli” (J 19,37; Za 12,10). Trzeba dostrzegać Przebitego w całym Jego życiu - także na etapie młodości przeszytym cieniem dojrzewania ku odkupiającej śmierci. Młody Chrystus musi być widziany przede wszystkim jako Zbawca, a dopiero wtedy jako Objawiciel. Dopiero i właśnie w Jego miłości do Ojca i do nas (bycie w sprawach Ojca) odsłania się młodość.

32 Por. Cz.S. Bartnik, Dogmatyka katolicka, dz. cyt., s. 589.

${ }^{33}$ Por. P. Seewald, Jezus Chrystus. Biografia, tłum. J. Jurczyński, Kraków 2011, s. 168 (dziennikarz cytuje wypowiedź św. Justyna).

${ }^{34}$ Por. A. Nichols, dz. cyt., s. 145: He marks the crisis of growth by asserting the rights of his heavenly father. 
Ponieważ Logos pociągnął do Ojca ciążącą ku światu ludzką naturę także w okresie dorastania, wyposażenie ludzkiej duszy (intelekt, wola i uczucia) młodego człowieka zostało uwolnione do życia w relacji z Ojcem. Większy jest Ten, który w młodych jest, niż ten w świecie (por. $1 \mathrm{~J} 4,4$ ). Odkupiony młodzieniec zostaje uzdolniony do współpracy z Bogiem, przy czym będzie się ona urzeczywistniała w różny sposób w ramach subiektywnej historii zbawienia. Na etapie nawrócenia ograniczy się do wolnej odpowiedzi i recepcji odkupienia obiektywnego dokonanego przez Chrystusa. Cały zaś proces współdziałania człowieka z Bogiem będzie opierał się na wszczepieniu w Ostatniego Adama, dzięki któremu „eschatologiczne moce” poprowadzą młodego człowieka od starego do nowego Adama.

Wcielenie otworzyło przed ludźmi możliwość uczestnictwa w życiu samego Boga ${ }^{35}$. Pochodzenie Jezusa w Łukaszowym rodowodzie zostaje doprowadzone do samego Adama, Syna Boga; w ten sposób Chrystus jawi się „nowym Adamem”, pierwszym z tych pochodzących bezpośrednio od Boga (por. Łk 3,38) ${ }^{36}$. Jezus jako eschatologiczny początek nowej ludzkości należy do Boga przez otrzymanie Ducha Świętego ${ }^{37}$. Młodość wydaje się okresem krytycznym w życiu człowieka; wcześniej, jako dziecko, zawdzięczał wszystko innym i niejako naturalnie pozostawał od nich zależnym, teraz chciałby brać wszystkie sprawy we własne ręce. Czuje się jak młody bóg i wydaje mu się, że zawładnie całym światem ${ }^{38}$. Jednak Wcielenie ukazuje, że w całym swoim życiu człowiek pozostaje synem podległym Ojcu. Należałoby pomóc młodemu w przejściu od bycia dzieckiem do bycia synem. Nie przez samowystarczalność, ale w posłuszeństwie syna - darze Ducha Świętego - osiąga się przebóstwienie ${ }^{39}$. Nikt tak wolny jak Syn poddany we wszystkim Ojcu.

35 Por. T. Rowland, dz. cyt., s. 137.

${ }^{36}$ Por. G.L. Müller, dz. cyt., s. 302.

${ }^{37}$ Por. R.J. Karris, Ewangelia według św. Łukasza, w: Katolicki komentarz biblijny, red. R.E. Brown, J.A. Fitzmyer, R.E. Murphy, red. wyd. pol. W. Chrostowski, red. nauk. W. Chrostowski, tłum. K. Bardski i in., Warszawa 2004, s. 1054.

${ }^{38}$ Interesujące $\mathrm{z}$ tej perspektywy wydaje się odczytanie jednej z pokus, którym został poddany Chrystus na pustyni.

39 Por. J. Ratzinger, Bóg Jezusa Chrystusa, dz. cyt., s. 69. 


\subsection{DUCHOWOŚĆ INKARNACYJNA}

Warunkiem życia prawdziwie ludzkiego nie jest zewnętrzne naśladowanie Chrystusa (byłby to pelagianizm), ale włączenie w Chrystusa (bycie/życie „w Chrystusie”) i pozwolenie Mu, by przeżywał w nas swoje misteria ${ }^{40}$. Jeśli wszelka Chrystusowa teandryczna aktywność wypływa ze źródła Jego dialogu z Ojcem, wtedy sequela Christi nie zaistnieje, jeśli podążający za Chrystusem znajdzie się poza tą synowską komunikacją. Konieczne zatem staje się uczestnictwo w modlitwie Jezusa ${ }^{41}$.

Ale przecież również to modlitewne centrum Jezusa - bycie sam na sam z Bogiem - dla nas pozostaje nieosiągalne. Łukasz wyraźnie ukazuje tę nieprzystawalność doświadczenia uczniów, a nawet samej Matki Bożej, do tego, co właściwe jedynie Wcielonemu. Dlatego Chrystus jawi się samotny, choć przebywa wśród uczniów: „gdy kiedyś modlił się sam i byli przy Nim uczniowie" (Łk 9,18) ${ }^{42}$. Ewangelista pośrednio wskazuje jednak drogę wyjścia z impasu. Wiemy, że gdy Dwunastoletni wyjawił swoją relację do Ojca i potrzebę bycia w Jego sprawach, „matka zachowywała wszystkie te słowa w swoim sercu” (Łk 2,51). Z kolei uczniowie, gdy pewnego razu skończył się modlić, poprosili: „Panie, naucz nas modlić się [...]" (Łk 11,1). Chodzi zatem nie o kopiowanie modlitwy (znów: byłby to pelagianizm), raczej młodych należałoby prowadzić do przeżycia duchowego wstrząsu w patrzeniu na Dwunastoletniego komunikującego się z Ojcem, a następnie do zachowywania i rozważania w sercu tego, co zostało zobaczone. $\mathrm{Z}$ tego popłynie zapewne prośba o łaskę włączenia w tę głęboką więź z $A b b a^{43}$.

Dopiero wtedy otworzy się droga do tego, żeby całe życie młodego stało się modlitwą, na wzór Wcielonego. Ostatecznie chodzi o syntezę kontemplacji i działania, czyli o duchowość zgodną z logiką Wcielenia ${ }^{44}$. „Modlitwa to nie kącik dla Pana Boga wykrojony z dnia powszedniego”45,

${ }^{40}$ Por. Katechizm Kościoła Katolickiego, Poznań 2009, nr 521 (dalej cyt. KKK).

${ }^{41}$ Por. J. Ratzinger, Tajemnica Jezusa Chrystusa, tłum. J. Płoska, Kielce 2005, s. 15 (teza I) i s. 25 (teza III). A. Riches, After Chalcedon, s. 211.

${ }^{42}$ Por. J. Ratzinger, Bóg Jezusa Chrystusa, s. 80; D.G. Bonagura, dz. cyt., s. 305.

${ }^{43}$ Por. D.G. Bonagura, dz. cyt., s. 296.

${ }_{44}$ Por. Franciszek, Adhortacja Apostolska Evangelii gaudium, Watykan 2013, 262.

45 A. Läpple, Powróćmy do modlitwy, tłum. J. Zychowicz, Kraków 1991, s. 145. 
ale i odwrotnie: dzień powszedni zostanie uświęcony jedynie pod warunkiem wejścia do kapliczki modlitwy, bo tylko w samym akcie kontemplacji dokonać się może przemiana rodząca się ze spojrzenia Chrystusa na człowieka $^{46}$. Wezwanie do działania nie pozostanie zapewne bez rezonansu w sercu młodego człowieka, który, by użyć obrazowego stylu papieża Franciszka, „chodzi na dwóch nogach jak dorosły, ale w odróżnieniu od dorosłych, którzy stojąc, trzymają nogi koło siebie, on zawsze ma jedną wysuniętą, gotów ruszyć, wystartowac" 47 .

\subsection{WOLNY PRZYMUS MISJI}

Podobnie wstrząsająca jest Łukaszowa relacja o młodym Chrystusie, który na pewno już w wieku dwunastu lat wiedział, że musi $(\delta \varepsilon \tilde{\imath})$ być

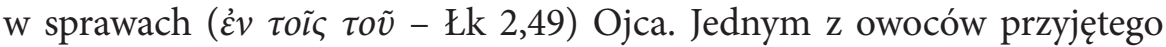
odkupienia będzie ten wewnętrzny „wolny przymus” pełnienia woli Bożej. Właśnie ze względu na posłuszeństwo Chrystusa tej przeżywanej w ludzkiej duszy powinności - odkupienie (również okresu młodzieńczego) mogło się dokonać. Dlatego owo pragnienie zaangażowania w sprawy Ojca nie dotyczy jedynie Chrystusa, ale również Jego naśladowców.

Paweł dla przykładu „musi” być świadkiem Chrystusa i głosić Słowo Boże wszędzie. „Gdy tam [do Jerozolimy] przyjdę, będę musiał $(\delta \varepsilon \tilde{\imath})$ i Rzym odwiedzić” (Dz 19,21). Pewnego razu zachęca go Pan: „Bądź dobrej myśli, jak bowiem w Jeruzalem dałeś świadectwo w sprawach mnie dotyczących, tak trzeba $(\delta \varepsilon \tilde{\varepsilon})$, abyś i w Rzymie był takim świadkiem" (Dz 23,11). Z kolei apostoł narodów motywuje współpracownika Tymote-

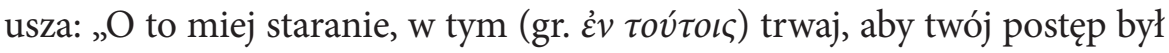
widoczny dla wszystkich” (1Tm 4,15) ${ }^{48}$. Bycie w sprawach Ojca oznacza zajęcie się nimi, trwanie $\mathrm{w}$ nich, oddawanie się im całym sobą ${ }^{49}$. Młody

${ }^{46}$ Por. H.Urs von Balthasar, Medytacja chrześcijańska, tłum. W. Szymona, Poznań 2014, s. 32.

47 Franciszek, Bóg jest młody. Rozmowa $z$ Thomasem Leoncinim, tłum. O. Styczeń, Kraków 2018, s. 16-17.

48 Por. H.J. de Jonge, dz. cyt., s. 335-336.

49 Por. tłumaczenie w Biblii Tysiąclecia: „W tych rzeczach się ćwicz, cały im się oddaj $[\ldots] "$. 
biskup ma: uczyć się i nauczać; nie ustawać w czytaniu oraz zachęcać innych; czuwać nad sobą i nad powierzonymi sobie (por. $1 \mathrm{Tm}$ 4,11-16).

Ze strony Kościoła należałoby wyczekiwać podobnych pragnień bycia w sprawach Ojca, a także podejmować próby rozbudzenia ich w młodzieży („nie” dla paternalizmu oraz zewnątrzsterowności). Należy wydobywać „na zewnątrz” to, co przez sakramentalne wszczepienie w Chrystusa zostało młodym już podarowane. Trzeba, mówiąc za Romano Guardinim, by Kościół budził się w duszach; dopowiedzmy: by w młodych Kościół mógł stawać się tym, czym jest w swojej istocie - Kościołem misyjnym. Nie istnieje, podkreśla papież Franciszek, podział na uczniów i misjonarzy, istnieją jedynie uczniowie-misjonarze ${ }^{50}$. Na tę ewangelizacyjną rolę młodych zwrócili uwagę polscy biskupi w 2008 roku $^{51}$.

Młodość nie jest „synonimem poczekalni dla oczekujących na swój czas”, dlatego Kościół nie może mówić młodym: „jeszcze nie nadeszło wasze «teraz»” - przekonywał niedawno Franciszek ${ }^{52}$. Owszem, „Bóg chce, aby młodzi mieli misję”, także „wśród innych młodych”, bo dopiero „bycie misjonarzami, w szerokim znaczeniu tego słowa, pozwala patrzeć na świat nowymi oczami, nie być już turystami życia, ale jego głównymi aktorami”. Częścią misji młodych jest według Biskupa Rzymu „wyjść na ulicę" i „ubrudzić sobie stopy” ${ }^{3}$.

\subsection{MŁODOCIANI PROROCY}

Następca Piotra zwraca także uwagę na misję prorocką właściwą okresowi młodzieńczemu, „młody człowiek ma bowiem w sobie coś z proroka i musi to odkryć" 54 . Również to powołanie do bycia prorokiem daje się odczytać w świetle teologii Wcielenia.

Logos wziął nie tylko człowieczeństwo z Matki Żydówki (por. KKK 423), ale razem $\mathrm{z}$ tym wszedł $\mathrm{w}$ historię zapowiadającą i przygotowują-

${ }^{50}$ Por. Evangelii gaudium, 120.

${ }^{51}$ Por. Rada ds. Duszpasterstwa Młodzieży, dz. cyt., s. 73.

${ }^{52}$ Por. Franciszek, Homilia $z$ Mszy posłania ŚDM $w$ Panamie, https://ekai.pl/ dokumenty/homilia-z-mszy-poslania-sdm-w-panamie/

${ }^{53}$ Franciszek, Bóg jest młody, s. 105. 128. Por. Evangelii gaudium, 106.

${ }^{54}$ Por. Franciszek, Bóg jest młody, s. 35. 
cą Jego przyjście, przyjmując całą religijną tradycję narodu wybranego, a zarazem dokonując jej najgłębszej z możliwych modyfikacji. Inkarnacja oznacza, że „formy myślenia i widzenia świata, znamiona swojej ludzkiej psychiki otrzymał Jezus od ludzi żyjących przed Nim i na koniec od swojej Matki”, a także „że wraz z dziedzictwem przodków przyjął w siebie całą skomplikowaną drogę, jaka od Marii prowadzi wstecz do Abrahama, a w końcu aż do Adama"s5.

Jak ukazuje się to już w epizodzie świątynnym, z jednej strony Słowo, które stało się Żydem, uświadamia sobie swoją tożsamość w związku $\mathrm{z}$ tradycją religijną, z drugiej ją przekracza. Samorozumienie pojawia się właśnie w dialogu najpierw z Rodziną, potem z nauczycielami w świątyni, oraz na tle uroczystości żydowskich. Jednak właśnie w tym dialogu czy nawet konfrontacji odkrywa to, co jest tylko Jego udziałem, a przez to, że transcenduje zastałą religię, może przemienić ją „od wewnątrz”. Musi się niejako odbić od tego, co zastał; nie tylko dlatego, że wszedł w historię grzesznych ludzi potrzebujących odkupienia, skoro i Niepokalanie Poczęta, łaski pełna (por. Łk 1,28) Matka Pana nie pojmuje misterium Syna (por. Łk 2,50).

Jeśli perykopę odczytać alegorycznie, w Najświętszej Maryi Pannie widząc pierwowzór Kościoła (łac. typus Ecclesiae), wtedy stosunek Dwunastoletniego Syna do Matki byłby analogiczny do stosunku zachodzącego między radykalnie oddanym Bogu młodym człowiekiem a Kościołem „zastanym”. Na ile życie uświęconego członka Kościoła odpowiadałoby misterium Kościoła, na tyle stawałby się on prorokiem dla Kościoła grzesznego w swoich członkach, strukturach czy praktykach. Mimo że Kościół jako misterium nie istnieje nigdy poza Kościołem rzeczywistym, to z kolei „wcielenie” w aktualną postać nigdy w pełni nie odpowiada temu, czym Kościół jako misterium już jest ${ }^{56}$.

A wtedy, konsekwentnie, nie wolno utożsamiać się wiernemu $\mathrm{z}$ tą niedoskonałą postacią Kościoła, w której żyje ${ }^{57}$. Całkowitemu utożsamieniu się z Kościołem jako misterium winna towarzyszyć odwaga kwe-

55 J. Ratzinger, Bóg Jezusa Chrystusa, dz. cyt., s. 71.

${ }^{56}$ Por. S. Zatwardnicki, Kościół zgorszenia - tajemnica obrazy, Katowice 2018, s. 167.

57 Por. J. Ratzinger, Kościót - znak wśród narodów. Pisma eklezjologiczne i ekumeniczne, tłum. W. Szymona, Lublin 2013, s. 169. 
stionowania aktualnej postaci Kościoła. Tutaj wolno sytuować prorockie zadanie młodych. Należy młodym stwarzać warunki zakorzenienia w Tradycji, aby mogli odkrywać swoją chrześcijańską tożsamość oraz umysłem i sercem wnikać w istotę Kościoła (sentire cum Ecclesia). Ryzykując tym samym, że okażą się bardziej posłuszni Ojcu i Jego sprawom niż kościelnemu status $q u o^{58}$, co w ostatecznym rachunku wszystkim nam wyjdzie na dobre.

\section{ZAKOŃCZENIE}

W artykule wyznaczyłem ramy antropologicznych poszukiwań przez wskazanie istotnych chrystologicznych i soteriologicznych prawd. Wskazałem te, które okazać się mogły najbardziej użyteczne w interpretacji danych biblijnych niosących objawienie dotyczące tajemnicy młodości Chrystusa. W refleksjach skupiłem się na dwóch epizodach: zgubieniu-odnalezieniu się nastoletniego Żyda w świątyni oraz chrzcie dorosłego Jeszuy (por. Łk 3,21-22). Nie interesował mnie wiek biologiczny czy psychiczny, ale „teologia dojrzewania”, w świetle której można by wyjaśniać tajemnicę młodości ludzkiej. Na tej podstawie udało się w paragrafie czwartym wyartykułować istotne komponenty „młodości teologicznej”.

Należy zwrócić uwagę na cząstkowość przeprowadzonych badań, które zostały oparte na fragmencie ziemskiej historii Wcielonego, i to tej ukazanej jedynie przez Łukasza. Ewangelista w swoich ascetycznych relacjach z Chrystusowego dzieciństwa zamierzał zwrócić uwagę jedynie na istotne prawdy chrystologiczne i soteriologiczne, a wtórnie również antropologiczne. Dalsze poszukiwania wymagałyby sięgnięcia nie tylko do Mateuszowej Ewangelii dzieciństwa, ale do wszystkich ewangelistów i całych Ewangelii - można by prześledzić publiczną służbę Chrystusa pod kątem poszukiwania odpowiedzi na pytanie, w jaki sposób młodość przeżyta przez Wcielonego zaprocentowała w późniejszym dorosłym życiu na korzyść naszego zbawienia. Kto jednak powiedział, że zagadnienie przeglądania młodości w światłach chrystologii należy ograniczać jedynie do ziemskiej historii Wcielonego? Owszem, obiecujące jawi się spojrze-

\footnotetext{
58 Por. Evangelii gaudium, 33.
} 
nie na wiek młodzieńczy z perspektywy uwielbionego Pana, który działa w swoich, również młodocianych, naśladowcach.

\section{BIBLIOGRAFIA}

Balthasar H. Urs von, Medytacja chrześcijańska, Poznań 2014.

Bartnik Cz.S., Dogmatyka katolicka, t. I: Traktaty I-VI, Lublin 2012.

Biblia pierwszego Kościoła. Przełożył oraz przypisami opatrzył ks. Remigiusz Popowski SDB, Warszawa 2017.

Biblia Tysiąclecia: Pismo Święte Starego i Nowego Testamentu w przekładzie z języków oryginalnych. Opracowat Zespół Biblistów Polskich $z$ inicjatywy benedyktynów tynieckich, wyd. 5, Poznań 2003.

Bonagura D.G., Joseph Ratzinger/Benedict XVI's Christology of Jesus' prayer and two contemporary theological questions, "Nova et vetera" (2014) nr 1, s. 287-306.

Ernst M., Dojrzaly/Petnoletni, w: red. F. Kogler, R. Egger-Wenzel, M. Ernst, red. nacz. nauk. wyd. pol. H. Witczyk, Nowy leksykon biblijny, Kielce 2011, s. 151.

Fitzmyer J.A., List do Galatów, w: red. R.E. Brown, J.A. Fitzmyer, R.E. Murphy, red. wyd. pol. W. Chrostowski, red. nauk. W. Chrostowski, Katolicki komentarz biblijny, Warszawa 2004, s. 1370-1386.

Franciszek, Adhortacja Apostolska Evangelii gaudium, Watykan 2013.

Franciszek, Bóg jest młody. Rozmowa $z$ Thomasem Leoncinim, Kraków 2018.

Franciszek, Homilia $z$ Mszy postania ŚDM w Panamie, w: https:/ekai.pl/dokumenty/ homilia-z-mszy-poslania-sdm-w-panamie/ [06.03.2019].

Grabowski M., Pomazaniec. Przyczynek do chrystologii filozoficznej, Poznań 2010.

Grzegorz z Nazjanzu, Epistola CI.

Jan Paweł II, Encyklika Redemptor Hominis, Watykan 1979.

Jan Paweł II, List do młodych całego świata Parati semper.

Jonge de H.J., Sonship, wisdom, infancy: Luke 2:41-51a, "New Testament Studies" (1978) nr 3, s. 317-354.

Karris R.J., Ewangelia wedlug św. Łukasza, w: R.E. Brown, J.A. Fitzmyer, R.E. Murphy, red. wyd. pol. W. Chrostowski, red. nauk. W. Chrostowski, Katolicki komentarz biblijny, Warszawa 2004, s. 1034-1107.

Katechizm Kościoła Katolickiego, Poznań 2009.

Keener C.S., Komentarz historyczno-kulturowy do Nowego Testamentu, Warszawa 2000. Kreeft P., The Philosophy of Jesus, South Band, Indiana 2007.

Langkammer H.H., Komentarz do Ewangelii wg św. Łukasza i Ewangelii wg św. Jana, Poznań 2014.

Läpple A., Powróćmy do modlitwy, Kraków 1991.

Mickiewicz F., Ewangelia według świętego Łukasza. Rozdziały 1-11. Wstęp, przekład z oryginału i komentarz, Częstochowa 2011. 
Międzynarodowa Komisja Teologiczna, Teologia, chrystologia, antropologia.

Międzynarodowa Komisja Teologiczna, Wybrane zagadnienia z chrystologii.

Müller G.L., Dogmatyka katolicka, Kraków 2015.

Nichols A., Epiphany. A Theological Introduction to Catholicism, [b.m.] 2016.

O'Collins G., Revelation. Towards a Christian Interpretation of God's Self-revelation in Jesus Christ, Oxford 2016.

Papieska Komisja Biblijna, Naród żydowski i jego Święte Pisma w Biblii chrześcijańskiej, Kielce 2002.

Pismo Święte Starego i Nowego Testamentu. Najnowszy przekład z języków oryginalnych z komentarzem. Opracował Zespół Biblistów Polskich z inicjatywy Towarzystwa Świętego Pawła, Częstochowa 2009.

Rada ds. Duszpasterstwa Młodzieży, Młodość z Chrystusem. Biskupi polscy do młodzieży, Tarnów 2008.

Ratzinger J. (Benedykt XVI), Jezus z Nazaretu, cz. 1: Od chrztu w Jordanie do Przemienienia, Kraków 2007.

Ratzinger J. (Benedykt XVI), Jezus z Nazaretu. Dzieciństwo, Kraków 2012.

Ratzinger J., Bóg Jezusa Chrystusa. Medytacje o Bogu Trójjedynym, Kraków 1995.

Ratzinger J., Kościót - znak wśród narodów. Pisma eklezjologiczne i ekumeniczne, Lublin 2013.

Ratzinger J., Tajemnica Jezusa Chrystusa, Kielce 2005.

Riches A., After Chalcedon: the Oneness of Christ and the Dyothelite Mediation of his Theandric Unity, "Modern Theology" (2008) nr 2, s. 199-224.

Riches A., Ecce homo. On the Divine Unity of Christ, Grand Rapids, Michigan 2016.

Rowland T., The Humanism of the Incarnation. Catholic, Barthian, and Dutch Reformed,

"Nova et Vetera" (2015) nr 1, s. 135.

Seewald P., Jezus Chrystus. Biografia, Kraków 2011.

Sobór Chalcedoński, Definicja wiary, w: Dokumenty Soborów Powszechnych. Tekst grecki, łaciński, polski. Tom I. Nicea I, Konstantynopol I, Efez, Chalcedon, Konstantynopol II, Konstantynopol III, Nicea II. (325-787), układ i oprac. A. Baron, H. Pietras, Kraków 2007, 214-224.

Sobór Watykański II, Konstytucja duszpasterska o Kościele w świecie współczesnym Gaudium et spes.

Sokołowski P., Chrystocentryzm młodości w orędziach Jana Pawła II, Benedykta XVI i Franciszka na Światowe Dni Młodzieży, „Ateneum kapłańskie” (2016) t. 167, z. 1, s. $39-56$.

The Radical Orthodoxy Reader, ed. J. Milbank, S. Oliver, New York 2009.

Weinandy T.G., Jesus the Christ, [b.m.] 2017.

Zatwardnicki S., Kościół zgorszenia - tajemnica obrazy, Katowice 2018. 